\title{
USING INTERDISCIPLINARY CONNECTIONS IN TEACHING ELEMENTARY CHEMISTRY
}

\author{
Akhmadjon Mirzayevich Jumanov \\ Associate Professor, Kokand State Pedagogical Institute Named After Mukimiy, Uzbekistan \\ Rakhmonjon Khaydarov \\ Undergraduate Student,Kokand State Pedagogical Institute Named After Mukimiy,Uzbekistan
}

\section{ABSTRACT}

The article uses interdisciplinary communication in teaching elementary chemistry in the course "Chemistry" in secondary schools. Materials on pedagogical research and their results.

KEYWORDS:- Integration, interdisciplinary communication, teaching chemistry, integrative course content, biogenic elements, macrobiogenic, microbiogenic and ultramicrobiogenic elements, scientific and pedagogical research, the system of continuing education, pedagogical experiments.

\section{INTRODUCTION}

Implementation of the tasks set by the Decree of the President of the Republic of Uzbekistan dated August 12, 2020 No.4805 "On measures to improve the quality of continuing education and scientific efficiency in chemistry and biology" and other regulatory legal acts on chemistry and biology. the organization of modern education is relevant. One of the urgent tasks today is to ensure the implementation of such important educational decisions, the integration of disciplines into chemical education, pedagogical research of the interdependence of disciplines and their further development. The role and importance of the formation of a holistic worldview in students, ensuring the interaction of chemistry and biological sciences in the formation of their natural science worldview are incomparable.
Main part. When conducting pedagogical research on the teaching of elementary chemistry on the basis of interdisciplinary relevance, first of all, it is necessary to rework the content of educational materials on an integrative basis. In the school chemistry course, special attention is paid to the role of elements in the periodic table, their atomic structure, distribution in nature, physical and chemical properties and their biological significance.

We know that the material world, including living organisms, is made up of chemicals, chemicals are made up of molecules, and molecules are made up of chemical elements. To date, more than 118 chemical elements have been identified, 92 of which are found in nature. More than half are part of biological systems. 18 elements perform biologically important functions in the body. 6 of them $(\mathrm{H}, \mathrm{C}, \mathrm{O}, \mathrm{P}, \mathrm{S}, \mathrm{N})$ 
are proteins, nucleic acids. The remaining 12 elements ( $\mathrm{Na}, \mathrm{K}, \mathrm{Ca}, \mathrm{Mg}, \mathrm{Mn}, \mathrm{Fe}, \mathrm{Co}, \mathrm{Cu}, \mathrm{Zn}, \mathrm{Mo}, \mathrm{Cl}$, J ) participate in the life of the body. The 10 metals they contain are called biometals. These elements differ from each other in their atomic structure, chemical properties and quantity in the body.

Living organisms contain a large number of elements (oxygen, carbon, hydrogen, nitrogen, calcium, magnesium, sodium, phosphorus, sulfur, chlorine), which are common in nature.

The classification of nutrients is based on the following characteristics: By electronic structure:

- Biogenic s-elements: $\mathrm{Li}, \mathrm{Na}, \mathrm{K}, \mathrm{Mg}$, Ca, etc.;

- Biogenic p-elements: O, C, S, Si, P, etc.;

- Biogenic d-elements: $\mathrm{Mn}, \mathrm{Fe}, \mathrm{Zn}, \mathrm{Co}, \mathrm{Cu}, \mathrm{Ni}$ $\mathrm{Sr}, \mathrm{Mo}$ and others. By the amount of these elements in the body:

- Macrobiogenic elements - elements with a total content of $0.01 \%$ or more in the body. These include $\mathrm{O}, \mathrm{C}, \mathrm{H}, \mathrm{N}, \mathrm{S}, \mathrm{P}, \mathrm{Ca}, \mathrm{Na}, \mathrm{K}, \mathrm{Mg}$ and others;

- Microbial elements - elements, the total amount of which in the body is $10 \sim 3-10 \sim$ $5 \%$. These include $\mathrm{Mn}, \mathrm{Co}, \mathrm{Cu}, \mathrm{Mo}, \mathrm{Zn}, \mathrm{F}, \mathrm{J}$ and others;

- Ultramicrobiogenic elements - elements with a total content of less than $10 \sim 5 \%$ in the body. These include $\mathrm{Au}, \mathrm{Ss}, \mathrm{Bi}, \mathrm{Hg}$ and others.

Now let's turn to the content of materials related to the integrative content of some biogenic elements in teaching elementary chemistry.

When teaching the subject of non-metals, we recommend the following: In general, students should be aware that living systems cannot exist without halogens. It should be borne in mind that the emergence and development of life on Earth is directly related to oxygen, sulfur and their compounds and should be considered as a scientific and methodological problem, keeping this issue in the center of attention in teaching chemistry. We recommend that science teachers use the following teaching materials to teach the biological significance and physiological effects of fluoride from halogens: fluoride is $0.01 \%$ by weight of tooth enamel (a compound chemically close to apatite). The body receives the necessary fluoride from water (the rate of fluoride in water is $1 \mathrm{mg} / \mathrm{l}$ ). If a person lacks or has too much fluoride in the body, the tooth will begin to decay and damage the bones.

A decrease in the level of fluoride in the water leads to tooth decay (tooth decay). Fluorine is found in the body in combination with activators of calcium, magnesium and other enzyme systems. When a large amount of fluoride enters the body, they replace iodine and disrupt the thyroid gland.

As for chlorine, it is believed that $1 \cdot 10-2 \%$ of chlorine is present in the human body, is present in the extracellular fluid of the cell and participates in the formation of hydrochloric acid. $0.4-0.5 \%$ gastric juice, accelerates protein hydrolysis, increases the activity of protolytic enzymes, has bactericidal properties. The human body contains about $0.25 \%$ chloride ion. These ions affect the electrical conductivity of cell membranes, participate in the formation of the blood buffer system and water-salt metabolism.

Sodium chloride is important in human life. The daily human need for salt is 5-10 g. An increase in the amount of salt in the body makes you feel thirsty. Large amounts of salt are harmful to the body, causing high blood pressure and dementia.

In the thyroid gland, iodine is $10-3-10-5 \%$. The hormone thyroxine (a compound of iodine) is necessary for the normal life of a living organism. Iodine deficiency causes goiter [1; pp. 27-31].

Iodine occurs naturally in the form of sodium 
CURRENT RESEARCH JOURNAL OF PEDAGOGICS 2(7): 11-15, July 2021

DOI: https://doi.org/10.37547/pedagogics-crjp-02-07-03

ISSN 2767-3278

(C)2021 Master Journals

\section{Crossref do) 8 Google}

Accepted 23 thJuly, 2021 \& Published 28 ${ }^{\text {th }}$ July, 2021

and potassium iodides. $1 \cdot 10-6 \%$ of the body. Iodine plays an important role in metabolism. It is mainly found in onions and sea fish. Iodine is the main component of the hormones thyroxine and triiodothyronine. When the amount of iodine in the body increases, the activity of the thyroid gland is disrupted, which dramatically reduces the production of hormones.

Molecular iodine has an antimicrobial effect; its solutions are used to treat wounds. In medicine, an alcoholic solution of iodine $5-10 \%$ is used to combat microbes. Iodine is absorbed into the body and actively affects the metabolism, accelerates the process of dissimilation and participates in the synthesis of thyroxine, improves the activity of the thyroid gland. The body's daily need for it is $0.1 \mathrm{mg}$ [2; pp. 11-13].

Of the most important non-metals, special attention should be paid to oxygen and its biological significance.

Oxygen is found freely in nature and in the form of compounds. It makes up about half of the earth's crust. Air is $23.2 \%$ by weight and $20.9 \%$ by volume. $88.89 \%$ of the water is oxygen. Oxygen is found in proteins, carbohydrates and fats in soil, sand, various stones, plants and animals (65\% of the human body). Oxygen is involved in combustion and respiration. Under the influence of atmospheric oxygen, metal corrosion and decomposition of organic substances occur. Rapid accumulation of substances with oxygen is called combustion, and slow accumulation is called oxidation [3;pp. 1-30].

Oxygen plays an important role in life. The biological role of oxygen is to obtain electrons by binding (electron acceptor). The electrons of the food molecules of various organisms have a higher energy value than oxygen. Thus, energy is released due to the passage of electrons through nutrients (carbohydrates, fats and sometimes inorganic substances in bacteria: H2S, even iron), and this energy is used for chemical synthesis and other processes in the body [4; pp. 6-11].

In living organisms, oxygen plays the role of an acceptor (electron receptor) of an oxidant and is a participant in aerobic processes in life. When teaching the biological and physiological value of nitrogen and phosphorus, the following should be considered. Many organic compounds of plants and animals contain nitrogen. For example: hemoglobin, chlorophyll, some vitamins, hormones, nucleic acids and proteins. So, nitrogen is one of the most important elements for life. Ammonium nitrate - NH4NO3 is a hygroscopic salt consisting of colorless crystals with 5 different crystalline forms. It dissolves well in water, explodes under the action of a detonator in a dry state and under the influence of organic additives, metals or metal oxides; Ammonium nitrate is also called ammonium nitrate. It is used as fertilizer in agriculture and in the preparation of explosives - ammonia, which are used to demolish buildings. Nitric acid is used in the production of nitrogen fertilizers, sulfuric acid, medicines and various nitrates [5; pp. 100-103].

When teaching the "Metals" sections, it is necessary to pay attention to the following: given that metals are the main pillars and useful servants of vital systems, future biology teachers should provide comprehensive knowledge in this regard. Without such knowledge, it is impossible to completely form a biological worldview.

Sodium and potassium are biogenic s-elements of group I and are necessary for the normal functioning of the body. They are present in all human organs. These elements are macronutrients. Potassium ensures the smooth process of plant photosynthesis and plays an important role in plant germination. Potassium ions are part of the intracellular fluid, and sodium ion is part of the intercellular fluid.

The ratio of potassium and sodium ions in a 
CURRENT RESEARCH JOURNAL OF PEDAGOGICS 2(7): 11-15, July 2021

DOI: https://doi.org/10.37547/pedagogics-crjp-02-07-03

ISSN 2767-3278

(C)2021 Master Journals

\section{Crossref do) 81 Google}

Accepted 23thJuly, 2021 \& Published 28 ${ }^{\text {th }}$ July, 2021

certain concentration ensures the normal functioning of the body. In a living organism, potassium improves the functioning of the brain, nerves and heart. This allows nerve impulses to pass through the $\mathrm{Na}+$ ion fiber. Potassium ions are essential for the normal functioning of the heart and brain. In a living organism, there is less potassium ion than sodium ion. Potassium ions are harmful if they increase in the body.

Sodium is found in various biomolecules in the form of ions. Its content in the human body is $0.25 \%$. The daily sodium requirement is $4-7 \mathrm{~g}$. The amount of sodium in the blood is $0.32 \%$. Its ions help maintain water balance in the body. It, along with the ions $\mathrm{Mg} 2+, \mathrm{Ca} 2+, \mathrm{K}+, \mathrm{Cs}+$, is important for the absorption of nerve impulses and the maintenance of normal muscle condition.

Lesson plans for studying the structure of living organisms and their participation in biochemical processes were developed and used in the educational process.

Part of a pedagogical experiment. In the educational process, student materials on elementary chemistry of integral content were used. Grades 8A and 8B of secondary school No. 48 of Uchkuprik district of Fergana region were chosen as the object of the pedagogical experiment.

Initially, students' knowledge of elementary chemistry, biological function of elements, knowledge and practical skills of biogenic elements were tested on the basis of oral questioning. According to the results, the quality of assimilation and knowledge of students on the topic did not correspond to the high indicators we expected.

To ensure the reliability of the results of the experiments, the classes were divided into experimental and control. Class $8 \mathrm{~A}$ was designated as an experimental class and class $8 \mathrm{~B}$ was designated as a control group. In the experimental class, we used educational materials of integrative content on the biological significance of the elements we developed, their functions in a living organism. The control group used training materials on a common topic.

\section{Conclusion}

On the basis of experiments carried out in both grades, the quality of students' practical knowledge and skills on the topic was retested for comparison.

The analysis showed that the quality of assimilation and knowledge on the chosen topic in the experimental class significantly differs in comparison with the control class.

In conclusion, we can say that the assimilation by students of educational material of integrative content serves as the basis for the formation of holistic knowledge in students, the formation of their natural-scientific worldview.

\section{RefERENCES}

1. Радецкий А.М. О связи неорганической химии и медицины // Химия в школе. Москва, 2007. - №7.- С.27-31.

2. Файзуллаева Н.С., Хидирова Б. Талабаларни интеграциялашган таълимга тайёрлашнинг ташкилийметодик хусусиятлари // Фанларни интеграциялаб ўқитишнинг педагогик шарт-шароитлари: Республика илмийамалий конференцияси материаллари.Тошкент:ЎзПФИТИ, 2007.- Б.73-75.

3. Давидова М.Н.,Савинкина Е.В. Кислород (Сценарии уроков. 8 класс) - М. : Чистые пруды, 2006. - 30 с.

4. [69;6-11-б.]. Мартыненко Б.В., Михалёва М.В, Гариева Н.Ф. Химия дыхания // Химия в школе. - Москва, 2008. - №5. - 
CURRENT RESEARCH JOURNAL OF PEDAGOGICS 2(7): 11-15, July 2021

DOI: https://doi.org/10.37547/pedagogics-crjp-02-07-03

ISSN 2767-3278

(C)2021 Master Journals

Crossref dof 81 Google

Accepted 23thJuly, 2021 \& Published 28 $8^{\text {th }}$ July, 2021

\section{C.6-11.}

5. Мартыненко Б.В., Михалёва М.В, Гариева Н.Ф. Химия дыхания // Химия в школе. - Москва, 2008. - №5. - С.6-11. 